\title{
Title
}

Horrorism in the scene of torture: reading Scarry with Cavarero

\section{Name of author}

Timothy J. Huzar

\begin{abstract}
In this article I read Elaine Scarry's account of torture in her The Body in Pain (1985) alongside Adriana Cavarero's account voice and its relationship to violence in her A più voci: Per una filosofia dell'espressione vocale/For More than One Voice (2005) and Orrorismo: Ovvero della violenza sullinerme/Horrorism (2011). This serves a dual purpose: first, to demonstrate that Scarry's account of torture is implicitly committed to an Aristotelian distinction between phone and logos which mirrors Cavarero's account of 'The Devocalization of Logos' (2005: 33); and second, to probe the limits of Cavarero's notion of "horrorism" by reading it against Scarry's account of torture and some of Cavarero's own examples from For More than One Voice. Unlike Cavarero, for whom torture is a form of horrorism because it effaces the uniqueness of the prisoner, I argue that Scarry's account of torture demonstrates the gross reverence that torturer pays to the prisoner's uniqueness. In this way I argue that torture places the prisoner's uniqueness into a suspended state of dissolution.
\end{abstract}

\section{Keywords}


voice

speech

torture

Scarry

Cavarero

uniqueness

\section{Biography}

Timothy J. Huzar is a PhD student at the Centre for Applied Philosophy, Politics and Ethics, University of Brighton. His research looks at violence, vulnerability and the politics of being human, in relation to the work of Judith Butler, Adriana Cavarero, Elaine Scarry and Jacques Rancière. Tim is a member of the Critical Studies Research Group, and co-editor of the group's journal Critical Studies.

\section{Email Address}

T.Huzar@brighton.ac.uk

\section{Street Address}

School of Humanities

University of Brighton

10-11 Pavilion Parade

Brighton 
BN2 1RA

United Kingdom 


\section{Horrorism in the scene of torture: reading Scarry with Cavarero}

Timothy J. Huzar

University of Brighton

The relationship between the voice and violence, in particular the violation of the body, has a long intellectual and cultural history, one which has been explored by Elaine Scarry and Adriana Cavarero in their respective texts The Body in Pain (1985) and A più voci: Per una filosofia dell'espressione vocale/For More than One Voice (2005). In this article I read Scarry's account of the structure of torture, found in the first chapter of The Body in Pain, alongside Cavarero's For More than One Voice and Orrorismo: Ovvero della violenza sull'inerme/Horrorism (2011). This serves a dual purpose: on the one hand to clarify the underlying rationale in Scarry's account of torture; and on the other to link Cavarero's notion of 'horrorism' (ibid. 29) to what she describes in For More than One Voice as 'a vocal phenomenology of uniqueness' (2005: 7).

In the first half of this article I argue that Scarry's account of torture is implicitly committed to an Aristotelian distinction between phone and semantike. This becomes apparent when one reads The Body in Pain via Cavarero's account of logos found in For More than One Voice. Further, however, I argue that resources can be found in Scarry's account of torture that undermine this distinction: on closer inspection Scarry's account can be read as challenging the primacy of semantike over phone, indicating that the cries of the body in pain communicate a uniqueness that is indifferent to the semantic content that has been supposedly destroyed in the scene of torture. Scarry 
and Cavarero's accounts compliment one another, in that Cavarero's insistence on the importance of the distinction between phone and semantike is made starkly clear in Scarry's account of torture. I argue that in Scarry's account, the torturer violently enacts what Cavarero describes as the devocalisation of logos (ibid. 33): that is, the tendency in the western metaphysical tradition to ignore the fact that logos is both semantike and phone - that it is both reasoned speech and mere voice - and instead privilege only the semantic component. In effect, in the scene of torture that Scarry portrays, the process of torture actualises this devocalisation of logos through the infliction of violence (and the manifesting of pain) in the body of the other. In torture the body in pain is made to force the separation of phone from semantike, positioning semantike with the torturer and phone with the body in pain. The embodied voice of the prisoner is used as a vehicle for the disembodied reason of the torturer, thus ridding the torturer of his dependence on the materiality of his body. In this way, I argue, in Scarry's account of torture the torturer attempts to speak without his body.

The second half of the article proceeds to contrast Cavarero's account of the ethical implications of the exposure to extreme forms of violence - an account which is formalised in Horrorism but is present in prefigurative form in For More than One Voice with Scarry's account of torture. I argue that what is particularly horrifying in Scarry's account of torture is not the torturer's disregard for the singular uniqueness of the prisoner - Cavarero's central ethical concern - but rather the torturer's recognition and exploitation of this singular uniqueness; the manner in which the torturer places this uniqueness in a suspended state of dissolution. This is made apparent by reading two 
examples that Cavarero deploys in For More than One Voice - the nymph Echo and the child Hurbinek - in the light of her more recent account of horrorism. Finally, by reading these examples in this manner I pose some critical questions to Cavarero's account of the human voice as being 'destined to speech' (2005: 211).

\section{The devocalisation of the pained body's logos}

In the first chapter of The Body in Pain Scarry offers a 'structure' (1985: 27) of torture, thinking through the phenomenology of the unilateral exposure to extreme pain that is characteristic of torture. Central to the structure of torture, for Scarry, is the distinction between the body and the voice: put briefly, when one is exposed to extreme pain one's sense of language, self and world, typified by voice, are placed in a process of destruction, while one's sense of body becomes utterly overbearing (ibid. 35). For Scarry, speaking and thinking, both forms of self-extension, become increasingly difficult under extreme pain. When one is in pain one cries out; language typically evades the person in extreme pain, as does, so Scarry argues, thought. Scarry uses 'voice', 'speech' and 'language' interchangeably throughout the second chapter of The Body in Pain, but what is most prominent in the chapter is the process whereby the semantic content of speech is destroyed in the experience of extreme pain, leaving one with groans, wails and cries. As such, if Scarry does not make explicit reference to the Aristotelian conception of Man, it is nonetheless implicit throughout her account of torture. For Aristotle, Man (always Man, and this is not insignificant) was understood as 
the zoon logon echon - 'the living creature who has logos' (Cavarero 2005: 34) as Cavarero interprets it. Cavarero reminds us that logos was figured in the Greek tradition as phone semantike, that is, as semantic voice, or what often gets translated simply as 'speech' (although as we will see this single word elides the fact that implicit in logos are two, albeit inseparable, conceptions: semantike and phone). Far more than mere voice, Man possesses speech. It is the semantike of logos - its capacity to signify, to endow Man with reason - which is significant. The semantike of logos distinguishes Man from other creatures and other animals: if Man signifies through his speech, for other animals they are limited by their mere voice, their cries and wails simply being signs of pleasure and pain. Slaves and women would, for Aristotle, fall somewhere between the two: they do not possess speech - otherwise they would be the equal of Man - but they can recognise speech - otherwise Man could not make productive use of them (Aristotle 1992: 69). ${ }^{1}$ Stuart Elden is certainly right to point out that it is important to remember that the having or the possession of logos was not simply a unilateral having or possession: he says, 'in reading the term zoon logon echon we should bear in the mind that to say that the human is the animal or being that has language is not to say that humans merely possess it, but that they are, at the same time possessed by it' (2005: 286). Nonetheless, in the Hellenic philosophical tradition there is an overwhelming sense that for slaves and for women they are far more possessed by logos than they are the possessors, and similarly that animals are utterly possessed by passions which dictate their vocalisations, and that if Man is possessed by logos it is a possession

\footnotetext{
${ }^{1}$ Cf. Page DuBois, Torture and Truth (1991: 66).
} 
which never calls into question his presumed reason and rationality.

For Cavarero then, phone and semantike, while both being central to the philosophical understanding of logos, are not equally recognised in this tradition. Semantike is consistently privileged over phone, a privileging which, Cavarero suggests, operates through clear gendered stereotypes. For Cavarero:

the symbolic patriarchal order that identifies the masculine with reason and the feminine with the body is precisely an order that privileges the semantic with respect to the vocal. In other words, even the andocentric tradition knows that the voice comes from "the vibration of a throat of flesh" and, precisely because it knows this, it catalogues the voice with the body. The voice becomes secondary, ephemeral, and inessential reserved for women (2005: 6).

In For More than One Voice and much of her other work, Cavarero attempts to disrupt this partitioning of the human (with its concomitant privileging of Man) not simply by claiming that women are in fact the possessors of speech, but further by insisting on the significance of the vocalic quality of phone, not only for women but for 'the incarnate singularity of every existence insofar as she or he manifests her- or himself vocally' (ibid. 7). Cavarero's central concern is to stress that 'logocentrism radically denies to the voice a meaning of its own that is not always already destined to speech' (ibid. 13). Cavarero argues that prior to any communication of semantic content the voice first communicates the uniqueness of the person who is vocalising: 'the truth of the vocal [...] proclaims simply that every human being is a unique being, and is capable of 
manifesting this uniqueness with the voice, calling and infecting the other, and enjoying this reciprocal manifestation' (ibid. 6-7). Cavarero's account of uniqueness is drawn directly from that of Hannah Arendt (1998: 176) and is a fundamental component of her theoretical project. Although the status of uniqueness and its relationship to the human cannot be fully explored in this article, critical questions will be raised towards this article's end which trace the limits of Cavarero's account of uniqueness, particularly as it relates to Cavarero's claim that voice is 'destined to speech' (ibid. 13). For now it should be noted that the status of uniqueness maintains an ambivalent relationship to the human: on the one hand uniqueness disarms a generalised conception of the human by insisting on each existent's concrete materiality; while on the other uniqueness, as proper to every human, is in danger of reproducing precisely this generality.

For Cavarero, uniqueness is consistently overlooked by a tradition that both only regards phone to the extent that it is the vehicle for semantike and further is committed to the theorisation of Man in general, rather than particular, non-generalisable men, or women, or many others. ${ }^{2}$ As Cavarero argues, even in lines of research 'dedicated to challenging the dominion of language, the voice of vocality insists on presenting itself as a voice in general' (ibid. 12). For the most part, however, phone is simply ignored when seen alongside semantike, or rather, following Cavarero, phone is captured by semantike (ibid. 35). This capturing renders phone superfluous, not only by making it

\footnotetext{
2 This is most clearly articulated in Cavarero's Tu che mi guardi, tu che mi racconti/Relating Narratives (2000), where Cavarero argues that "Man" is a universal that applies to everyone precisely because it is no one. It disincarnates itself from the living singularity of each one, while claiming to substantiate it' (ibid. 9).
} 
dependent on semantike, but further by privileging the visuality of semantike over the orality of phone:

[w]hat we call "signified" is, in fact, for metaphysics an object of thought that is characterized by visibility and clarity. The problem here is not only the relation between the realm of thought and that of speech, nor is it simply the usual metaphysical privileging of thought over speech. Rather, at stake is the fundamental gesture that locates the principle of the system of signification, of the signified, in the visual sphere (ibid.).

Cavarero continues: '[m]etaphysics has always dreamed of a videocentric order of pure signifieds. Verbal signification is, from its perspective, a hindrance - especially when it unfolds acoustically in vocal speech' (ibid. 40). Logos' ambivalent structure, referring both to reason and to voice, is collapsed, or always in the process of collapsing, towards the 'noetic' (ibid. 39) realm of knowledge governed by the static metaphors of vision and away from the dynamic metaphors of sound. The flesh of the body, and the sonority of sound from which reasoned speech can never escape, is effaced; logos is devocalised.

The devocalisation of logos becomes an especially pressing issue given that, as has been already indicated, logos plays a crucial role for Aristotle in distinguishing Man from other animals. The distinction rests on the possession of speech in the former, and this is central to Man's status as a properly political animal:

[Nature] has endowed man alone among the animals with the power of 
speech. Speech is something different from voice, which is possessed by other animals also and used by them to express pain or pleasure (Aristotle 1992: 60$)^{3}$

This account, and in particular Aristotle's separation of voice and speech, has been central to the conception of the human as it has been inherited in the western tradition (Bourke 2011: 7, 29-60; Rancière 1999: 1-19; Agamben 2007: 3-11). Cavarero notes that, following Aristotle, '[t]he voice prior to speech or independent of speech is therefore simply an animal voice - an a-logic and a-semantic phonation' (2005: 34). This is important when we consider Scarry's arguments concerning torture. For Scarry, when one suffers extreme pain one's capacity to deploy language - unequivocally the semantike of logos' signifying voice - is destroyed. There is something crucial to pain that, for Scarry, 'actively destroys' (1985: 4) language, 'bringing about an immediate reversion to a state anterior to language, to the sounds and cries a human being makes before language is learned' (ibid.). When thought through Aristotle's schema, in torture the semantike of logos is stripped away leaving nothing but phone; pure voice. It should be noted that the 'purity' of this desemanticised voice can already be called into question. As Joanna Bourke has demonstrated, to claim that pain robs speech of its semantic component is to ignore a plethora of counter-examples: in Bourke's words, 'the same people who declare their suffering to be "unspeakable" or "absolutely evanescent" may then go on to tell their story of pain in exquisite detail' (2014: 28).

\footnotetext{
${ }^{3}$ It should be noted that for Aristotle it is not speech per se that makes Man a political animal, but rather speech's function in signifying what is proper to the koinonia politike, or 'political community'. Cavarero's reading is exemplary on this account: see 'Logos and Politics' in For More than One Voice (2005: 183-188).
} 
Pain, notes Bourke, is 'inherently social' (ibid. 46): it is not an isolated experience within a person, as Scarry maintains, but rather emerges as a consequence of sociality. It is on this basis that Bourke charges Scarry with falling into the 'ontological trap' (ibid. 5) of conflating the metaphorisation of pain with with 'descriptions of an actual entity' (ibid.). Rather than pain being an entity that carries ontological weight and resides within people - fundamentally inaccessible to others and, as a consequence, destructive of forms of communication - Bourke proposes that one thinks of pain 'as an event' (ibid.). In this way one becomes a 'person-in-pain' (ibid.) through one's recognition, naming, and storying of one's pain, a process that 'can never be wholly private' (ibid. 6). However, as Bourke herself notes when reading Jean Améry's account of being tortured (Améry 1976), the 'extreme example' (Bourke 2014: 30) of torture is marked by 'incommunicability' (ibid.). In this way the hard distinction between pure voice and reasoned speech that has its roots in Aristotle is maintained in this article, not because it is deemed the correct account of pain, but because it has influenced understandings of extreme pain and thus can be mobilised to help make sense of them.

Following Aristotle's schema, torture is concerned with the forcible separation of speech from voice and thus concerned with the violent resolution of the ambivalence of logos: that it reduces one to an animalistic state 'anterior to language'. Or, perhaps more accurately, to an infantile state: unlike the animal, which is not presumed to have the capacity to possess the semantike of logos, the infant is understood as being 'destined to speech' (2005: 13) in Cavarero's words. ${ }^{4}$ As it will be argued towards the

\footnotetext{
${ }^{4}$ Cf. Giorgio Agamben's Infancy and History (2007).
} 
end of this article, the conclusion that the body in pain is animal or infantile can be refuted using resources that Cavarero offers, and this despite Cavarero's insistence on voice's 'destination to speech' (ibid. 210) which would otherwise unwittingly bolster this conclusion. First, however, it is necessary to offer a more detailed reading of Scarry's account of voice in the scene of torture. Scarry's account makes clear the crucial role violence plays in manifesting an understanding of Man as a disembodied, reasoning being, freed from an embodied voice and its associative lungs, throat and tongue, and necessarily actualised in relation to the violation of another. For Scarry, voice is important for two reasons: first, the torturer's voice objectifies the fact that the prisoner's voice has been, or is in a process of being, destroyed; second, the absence left by the stripping away of the language of the prisoner (the semantike of logos) is filled, or perhaps rather colonised, by the torturer.

Scarry argues that as well as inflicting pain the torturer also objectifies the destruction of the prisoner's world. The torturer does this by juxtaposing their world against the 'small and shredded world' (1985: 36) of the prisoner, and in so doing further contributes to the destruction of the prisoner's world. As Idelbar Avelar argues, '[i]n the modern technology of torture the moment of interrogation is constitutive of the infliction of pain' (2004: 31). Interrogation may be a common way of enacting this objectification, but it is not the only way. As Scarry says, '[t]he confession is one crucial demonstration of this absent world, but there are others' (1985: 38). These include the torturer's 'weapons, his acts, and his words' (ibid.); that is, the fact that he exists as an embodied, relational being, extending himself out into the world. The interrogation is a 
performative gesture, a particular strategy which exploits, bears witness to and objectifies the disjuncture between the world of the torturer (marked by myriad forms of self extension) and the world of the prisoner (which for Scarry extends barely beyond the surface of the prisoner's body). As Scarry argues, 'for the prisoner, the body and its pain are overwhelmingly present and voice, world, and self are absent; for the torturer, voice, world, and self are overwhelmingly present and the body and pain are absent' (ibid. 46). For Scarry there is thus a direct relationship between the prisoner's voice, self and world, and that of the torturer: the torturer instrumentalises the prisoner's deconstructed world to enlarge their own sense of world (and the regime that the torturer may represent): as Scarry says, '[i]t is only the prisoner's steadily shrinking ground that wins for the torturer his swelling sense of territory' (ibid. 36).

One can see, then, the intimate relationship between the fetishisation of disembodied reason - the semantike of logos, which as Cavarero rightly notes is always dominant over the embodied vocality of phone - and the infliction of violence on the other: following Scarry, a desire to rid oneself of body in the name of noetic reason is achievable through the making overwhelmingly present the body of another, via the medium of violence. ${ }^{5}$ It is precisely the absence of the semantike of logos in the other, achieved through the infliction of extreme pain, that is a condition for the attainment of this disembodied, reasoning, noetic being: for Cavarero, '[t]hought as male, the body loses its carnal reality and becomes a conceptual form' (2015b: 134). Torture, one could say, manufactures a sense of omniscience and omnipotence; an approximation of God,

\footnotetext{
${ }^{5}$ Cf. Page duBois, Torture and Truth (1991).
} 
or shock and awe; ${ }^{6}$ an 'apotheosis' in the original sense of the word. ${ }^{7}$ As Cavarero notes, it is precisely because logos cannot escape the vocality of phone that it needs to violently resolve its constitutive ambiguity by radically separating phone and semantike into their properly gendered expressions: the devocalisation of logos leaves the feminine figures to embody what remains - namely, the voice' (Cavarero 2005: 207).

Scarry makes the relationship between a desire for a disembodied reason and the violation of another clear in what is a centrally important passage from her account of torture. Scarry argues:

To assent to words that through the thick agony of the body can be only dimly heard, or to reach aimlessly for the name of a person or a place that has barely enough cohesion to hold its shape as word and none to bond it to its worldly referent, is a way of saying, yes, all is almost gone now, there is almost nothing left now, even this voice, the sounds I am making, no longer form my words but the words of another (1985: 35).

What is most apparent here is the separation of logos' phone semantike. Voice, or phone, is stripped of any capacity for signification it previously had; voice becomes 'the sounds I am making' which 'no longer form my words'. Crucially, however, the vocality

\footnotetext{
${ }^{6}$ Rachel Pain (2015) explicitly links experiences of domestic violence to military tactics such as shock and awe, arguing both that domestic violence, typically seen as an intimate violence, is also a political violence, and that the violence of war, typically seen as a political violence, is also an intimate violence. In both cases gender is crucial for conceptualising the dynamics of these scenes of violence, and I would suggest that the idealisation of the reasoning, disembodied Man as the universal subject of philosophy can also account for something of what is occurring in the 'shock and awe' domestic violence that Pain identifies (ibid. 67).

${ }^{7}$ Cf. Simona Forti's New Demons, where Forti argues that there is a relation between man's incapacity to approximate God's omnipotence and the infliction of extreme violence (2015: 93-94).
} 
of voice is not left simply to exist but rather forms 'the words of another'. The torturer in this manner rids himself of phone, colonising the phone of another which makes materially manifest the semantike of his logos, realising an ideal which has long been at the heart of the Western tradition. Understood in this way, the torturer is able to speak without his body. But there is another way of reading this passage, a way which concerns the question of communication.

As has been indicated, one can read this particular account that Scarry offers as being exemplary of the challenge that experiences of extreme pain pose: communication is radically undermined because the semantic content of said communication is estranged from the person who is vocalising. ${ }^{8}$ And yet, Scarry claims that the vocalising of this estranged semantic content is nonetheless 'a way of saying'. It would appear then that even after semantike is stripped from phone, the very process of this stripping is saying something: that is, something is being communicated. Scarry suggests that the content of the estranged speech of the one in extreme pain 'is a way of saying' that my voice is not my own; this is communicated despite the words not having enough cohesion to bond them to their 'worldly referent'. What Scarry is indicating is what is, for Cavarero, so frequently overlooked (or even actively effaced) in considerations of logos: that the semantike of logos is intimately connected to phone, and further that there is something communicated in phone which is utterly indifferent to semantic content. Phone is not a 'remainder' (Cavarero 2005: 13) or a 'leftover' (ibid.), rather it is an 'originary excess [...] the sphere of the voice is constitutively broader than

\footnotetext{
${ }^{8}$ For more on the 'estrangement' of pain see the second chapter of Joanna Bourke's The Story of Pain (2014: 27-52).
} 
speech' (ibid.). Whatever speech may communicate, first it communicates 'the acoustic, empirical, material relationality of singular voice' (ibid.), that is, 'a vocal phenomenology of uniqueness' (ibid. 7). ${ }^{9}$ Following Hannah Arendt, Cavarero argues that voice signifies first that there is a particular, unique existent: it communicates not what someone is but who they are. This who - expressed not through noetic reason but through embodied voice or, in another formulation of Cavarero's, not through philosophy but through narration (2000: 52) - is a non-generalisable who, a who which doesn't make the mistake of philosophy in asking after what Man (or even Woman) is, but rather who men and women (and many other people) are (ibid. 50). In Scarry's account uniqueness is communicated precisely because it is being violated: because there is a particular, non-generalised person - a who rather than a what - who is unilaterally exposed to extreme pain. ${ }^{10}$ As it will now be suggested, however, this uniqueness is not incidental to torture but is actively exploited by the torturer. This is, to use Cavarero's word, the 'horrorism' (2011) of torture, however a closer analysis of Scarry's account of torture will help clarify precisely what it is that is horrifying, in a way that will shift, even if only slightly, the account of horrorism offered by Cavarero.

\section{The horror of torture}

\footnotetext{
${ }^{9}$ To take Cavarero seriously, it is crucial to understand her claim of human uniqueness on its own terms; that is, it would be a mistake for one to read this claim as a generalised claim, when implicit in the claim is the recognition of specificity that is central to the notion of uniqueness. If all are unique, their uniqueness is theirs (even if it is inevitably tied up with the presence of others). By understanding uniqueness as a particular quality not of the human but of this human, the naive universalism that assumes all have equal access to uniqueness is avoided.

${ }^{10}$ Cf. Judith Butler's reading of Levinas in the final chapter of Precarious Life (2006: 133-134).
} 
In Horrorism Cavarero draws a distinction between terror and horror, arguing that the term "horrorism" is better able to account for various forms of contemporary violence, as well as maintaining a greater ethical valence in that it is articulated 'as though all the innocent victims, instead of their killers, ought to determine the name' (ibid. 3). Cavarero offers various examples of contemporary forms of horrorism: suicide bombing (ibid.); aerial bombing (ibid. 1-2, 27-28, 94-95); the London bombings of 7th July 2005 (ibid. 18-19); concentration camps (ibid. 40); and the torture conducted at Abu Ghraib (ibid. 106-115). What these examples indicate is that proper to horrorism is the destruction of the uniqueness of a person, often as it is expressed through the body (although it will be suggested that the body is not the central condition for an occurrence of horrorism), and that it is enacted on the helpless; that is, those who have no capacity to defend against it.

As a form of violence, horrorism 'offends the ontological dignity that the human figure possesses' (ibid. 9). Its principal target is the singular uniqueness of the human, which for Cavarero is most evident in the destruction of the body, particularly the head and face (ibid.). Horrorism is a 'violence whose precise aim is to erase singularity' (ibid. 19). In this sense the killing of the human is incidental to horrorism, even as it so frequently accompanies scenes of horror:

As its corporeal symptoms testify, the physics of horror has nothing to do with the instinctive reaction to the threat of death. It has rather to do with instinctive disgust for a violence that, not content merely to kill because killing would be too little, aims to destroy the uniqueness of the body, 
tearing at its constitutive vulnerability. What is at stake is not the end of a

human life but the human condition itself, as incarnated in the singularity of vulnerable bodies (ibid. 8).

Cavarero goes on: 'it is not so much killing that is in question here but rather dehumanizing and savaging the body as body, destroying it in its figural unity, sullying it [...] nullifying human beings even more than killing them' (ibid. 9). ${ }^{11}$ Torture, for Cavarero, typifies this most clearly: '[t]he dead body, no matter how mutilated, is only a residue of the scene of torture' (ibid. 31). ${ }^{12}$ The horror of torture also makes clear, for Cavarero, that what is proper to horrorism is its enactment on the 'helpless' or the 'defenseless' (ibid. 30):

[d]efenseless and in the power of the other, the helpless person finds himself substantially in a condition of passivity, undergoing violence he can neither flee from nor defend against. The scene is entirely tilted toward unilateral violence. There is no symmetry, no parity, no reciprocity. As in the exemplary case of the infant, it is the other who is in a position of

11 Cavarero here, as in many other places, is indebted to Hannah Arendt's analysis of the Nazi concentration camps and the killing of man's 'uniqueness' (Arendt 2003: 134-137). See also Cavarero's 'Narrative Against Destruction' (2015a: 4-5).

${ }^{12}$ As Cavarero notes, torture's etymology lies in the latin torquere: 'to twist and distort the body' (2011: 32). Torquere itself is linked to tortum, a wrong or injustice; cf. tort law, or Jacques Rancière's tort, translated as 'wrong' in the English versions of his Disagreement (Rancière 1999: 21; Panagia 2006: 91). Interestingly, the French supplice that Foucault draws on extensively in Discipline and Punish (1991), translated into the English as 'torture', is rooted in the latin supplicium, which signifies kneeling in supplication, as well as torture, punishment and suffering. 'Supplication' is rooted in the latin supplicāre, the plicāre meaning 'to bend'. So both examples of the infliction of suffering - torquere and supplicāre are linked to a torsional force, a twisting or bending, where the body comports itself in response to an outside power: either in deference (to bend one's knee) or in pain. 
omnipotence (ibid.). ${ }^{13}$

Importantly, in torture this is a manufactured helplessness: unlike the infant, who of necessity is vulnerable and helpless, the helplessness of the one subjected to torture is 'produced artificially [...] In this sense, torture belongs to the type of circumstance in which the coincidence between the vulnerable and the helpless is the result of a series of acts, intentional and planned, aimed at bringing it about' (ibid. 31).

The example of torture makes clear that while it is the violation of the helpless body that most frequently and visibly arouses repugnance, what is significant is that it is the singular uniqueness that this body avows that is at the heart of the scene of horror. This is important as for Cavarero, while the body (and especially the face) is an exemplar in exhibiting the singular uniqueness of the human, so too is the voice, not least because the voice for Cavarero is a properly embodied phenomenon (2005: 4). It is my argument that Cavarero's account of horrorism needs to be retroactively read back into her earlier text For More than One Voice, where two examples both demonstrate the origins of the notion of horrorism but also stress the vocalic significance of the phenomenon, something that is overlooked if one limits oneself to Horrorism. These two examples are centred around two people: first the nymph Echo as narrated by Ovid; and second the child Hurbinek, as narrated by Primo Levi.

\section{Echo}

\footnotetext{
${ }^{13}$ In the Italian, 'helpless' and 'defenseless' are 'l'inerme'. See the translator's introduction (2011: vi-viii) and Cavarero's account of the etymology (ibid. 30) for further discussion.
} 
In For More than One Voice Cavarero is centrally concerned with moments where voice becomes disembodied, and here the myth of the nymph Echo is a prime example. Of the three well-known versions of the myth (two from Ovid and one from Longus) Cavarero focuses on Ovid's original telling. Here, Echo - 'a loquacious nymph [...] possessed of a typically feminine rhetorical talent' (Cavarero 2005: 165) - distracts Juno through her words 'while the other nymphs bed Jupiter' (ibid.). Juno takes revenge on Echo by condemning her to 'repeat the words of others' (ibid.), but a repetition which is 'superimposed on the words that the speaker is pronouncing' (ibid. 166) so that only the last few words of Echo's repetition are heard. After this event Echo encounters Narcissus in a wooded glade. Echo is hidden from view behind a bush, repeating the words that Narcissus proclaims; however, only Echo's final words are distinctly heard by Narcissus:

the young boy invites her to join him. "Come here and let us meet [huc coeamus]," he says. And the voice of the nymph repeats, "Let us meet [coeamus]." Her response is naughty. For without the huc, coeamus alludes to coitus. The nymph goes on to make the situation worse by jumping out of the woods and throwing her arms around Narcissus. Scandalized by her ardor, the boy then declares that he would rather die than couple with her; and Echo, automatically, invites him to couple, or rather copulate, with her (ibid.).

Rejected by Narcissus, Echo begins to 'wither away' (ibid.) leaving 'a pure voice of resonance without a body $[\ldots]$ the beautiful nymph is sublimated into a mineralization of 
the voice' (ibid.). Echo becomes echo, the disembodied acoustic repetition of voice.

The withering away that Cavarero identifies is significant: Cavarero describes this as a 'nullifying' (ibid. 167) of Echo's body, and it is because the body is nullified that there is the 'definitive dissolution of a uniqueness' (ibid.). But in what sense is the body 'nullified' here? There is certainly a nullifying when Echo's body is reduced to stone, and importantly, as Cavarero highlights, 'not the stone of a statue, but rather stone in general: rocks, boulders, mountains' (ibid.). A statue would still reflect a uniqueness, even if in a reduced and sullied form. As stone, a part of the Earth but not, significantly, the soil (which would be akin to a burial and place Echo too close to a form of returning autochthon), Echo's uniqueness is effaced. But this is the finality of her dissolution: can the same be said for what occurs before? And further, what of the temporal dimension of this withering away? As Cavarero describes it, Echo's withering away has 'certain anatomical details: first her flesh dries up, then her humors vanish, and then her bones turn to stone' (ibid.). This is clearly a process; a violent and, importantly, a painful process. In this process Echo does not so much 'lose her body' (ibid.) or have her body nullified; rather, following Scarry, it seems that Echo's body is most present in this painful withering away: for the one exposed to extreme pain their body is felt as 'overwhelmingly present' (Scarry 1985: 46). There is certainly an ultimate nullifying, as Echo's human form is effaced in a manner which denies her the human ritual of burial (and, following Sophocles' Antigone, we might ask the question who mourns for Echo?), 14 but prior to this final nullifying, while there is certainly the threat of absolute

\footnotetext{
${ }^{14}$ Cf. Judith Butler's Antigone's Claim (2000).
} 
nullification, more importantly there is the processual deconstruction of the body and its concomitant singular uniqueness. ${ }^{15}$ If one only focuses on the nullifying of Echo's body as the 'definitive dissolution' (ibid.) of Echo's singular uniqueness, one effaces the pain which, as Scarry makes clear, is so central to extreme violent exploitation. Put the other way around, one can only conclude that Echo loses her body by ignoring the pain of a processual dissolution which makes the body not lost but on the contrary overwhelming, indeed, becomes overwhelming in direct relation to the absence of the semantike of logos. After all, Echo's experience perfectly illustrates the implicit devocalisation of logos that it is suggested is central to the structure of Scarry's account of torture. Cavarero notes that Echo's voice 'results, like residual material, from its subtraction from the semantic register of logos' (ibid. 166). Just as Scarry claims that in 'the thick agony of the body [...] this voice, the sounds I am making, no longer form my words but the words of another' (1985: 35), so too Cavarero argues that

If [Echo's] sounds, separated from the context of the sentence, come together to form words that still signify something (or something else), then this is a matter for the listener, not the nymph [...] Echo is no longer a zoon logon echon; she no longer possess phone semantike. She is instead pure phone, activated by an involuntary mechanism of resonance (2005: 166-167).

Echo's violent and painful dissolution is not incidental to this process but is central.

\footnotetext{
${ }^{15}$ Cf. Cavarero's reading of Polynices' imperiled disfiguring by wild beasts, and Antigone's desire to protect her brother's 'integral form' through burial (2002: 32-33).
} 
Although the temporal order of events does not match the account found in Scarry (in that Echo loses her semantic capacity prior to the infliction of violence on her body), nonetheless it is important that the violent, painful, processual character of her withering away is related in proximity to her 'desemanticization' (ibid. 167). It is worth noting that in Longus' account of Echo, her fate is to have her body torn to pieces so that only her voice remains (2002: 57$)$.

Although Cavarero suggests that there is a 'definitive dissolution' of Echo's uniqueness in the nullifying of her body, she does make clear that this uniqueness was already in an imperilled state: Echo's uniqueness was already in a state of precarity in the 'echo' of Echo's voice; Echo's voice as echo 'does not possess' (ibid.) uniqueness. Cavarero goes on:

Echo's voice is, in fact, not her voice; it does not possess an unmistakable timbre, and it does not signal a unique person. It simply obeys the physical phenomenon of the echo, repeating even the timbre of the other's voice. It is a mere acoustic resonance, a voice that returns, foreign, to the one who emitted it. The juxtaposition of Echo and Narcissus is therefore perfect. The absolute ego of Narcissus, for whom the other is nothing but "another himself," corresponds to the reduction of the vocalic nymph to a mere sonorous reverberation of the other. The mechanism of repetition in the voice produces the annulment of uniqueness (ibid. 167-168).

Two aspects of the scene concern Cavarero: the first is Echo's voice becoming a voice in general, a fact of nature which can be reproduced by anyone who, standing in front of 
a mountain, shouts; the second is Echo's voice being a particular voice, but a particular voice of another (in this instance Narcissus). In both cases what is problematic, for Cavarero, is the effacement of uniqueness; either in generality (the echo can be anyone's) or in specificity (the echo is not Echo's and is in fact Narcissus'). But nonetheless, if one sidesteps the violence of Echo's withering away what is missed is still the process of the processual dissolution of Echo's uniqueness, which contains within it the threat of final nullification but is not reducible to this final nullification. In this way Echo's experience is a scene of horror. The responsibility for her violation may, in Ovid's tale at least, fall somewhere between Juno and Narcissus in a way which obfuscates the violence of the devocalisation of logos, but that violence is nonetheless integral to the meaning of the scene. Indeed, Cavarero's reading almost perfectly mirrors Scarry's account of torture: Narcissus' 'absolute ego' corresponds to Echo's 'sonorous reverberation' in precisely the same way that the torturer's 'swelling sense of territory' (Scarry 1985: 36) corresponds to the prisoner's 'small and shredded world' (ibid.). Further, however, by reading the experience of Echo as a form of horrorism one can see that what is proper to the horror is not simply the final nullification of Echo's body, but more significantly the suspended state of dissolution her uniqueness, expressed through her body and voice, is placed in.

\section{Hurbinek}

In the closing of For More than One Voice, prior to her appraisal of Jacques Derrida, Cavarero offers some brief reflections on the other side of her thesis of vocalic 
uniqueness; that is, the destruction of this uniqueness (foreshadowing the work Cavarero will do in Horrorism). Following Arendt, Cavarero takes the Nazi Lager as a principle moment in the history of this destruction. Cavarero takes as her subject an account offered by Primo Levi, of the appearance of a child of approximately three years of age in the days after the liberation of Auschwitz (Levi 1987: 197-198). The child could not speak any discernable language; he was given the name Hurbinek. Although he could not speak, the child repeated a series of sounds in a manner which suggested a variation on a particular theme, which it was presumed were attempts to signify meaning, either his name or "to eat", or "bread"; or perhaps "meat"' (ibid. 198). For Cavarero, the destruction of voice and with it uniqueness, particularly the destruction of voice in a child (that absolutely defenseless existent) is of utmost importance: Cavarero's account of what it is to be human rests on this uniqueness. The destruction of this uniqueness exemplified in the Lager is thus not so much a challenge to her thesis (indeed, the opposite could be said to be true) but it does pose a challenge to the ethical efficacy of such a thesis. Of course, the challenge of the Holocaust to philosophers is not unique to Cavarero; nonetheless, this is an especially pressing issue for Cavarero given the primacy she affords to the vocalic as an expression of the particular, relational, singular uniqueness of the human. As Cavarero herself argues, '[a]ny present day reflection on horror must, sooner or later, come to terms with Auschwitz' (2011: 34).

Cavarero points out that '[t]he other deportees therefore attribute to the articulated sounds of the child the intention to signify' (2005: 211), a conclusion 
Cavarero seems content with. Cavarero goes on: 'Hurbinek's voice, precisely because it modulates variations on a theme, already makes its destination to speech perceptible' (ibid.). In Hurbinek's vocalic expressions, which further do not appear arbitrary but rather are related by a presumed theme which is approached through the variation and modulation of the vocalic (one can think here of musical improvisation), Cavarero hears Hurbinek's 'destination to speech' (ibid.). Earlier, Cavarero has suggested that 'speech is [voice's] essential destination' (ibid. 209); that, although both humans and animals share a voice, it is the destination to speech which distinguishes the human voice:

The humanity of human beings plays out precisely along the division (which is rooted in the vocalic) of this destination. Which means the interweaving of voice and speech, which is not necessary [sic] synchronous, cannot be severed without sacrificing humanity itself; this goes for both animal voice and the devocalized logos (ibid. 209-210).

'Hurbinek is saved' (ibid. 211) precisely because of his voice's destination to speech, a destination to speech which is identified by the modulations and variations around a particular theme, which may be his name, or may be something to eat, but in either case cannot be identified by its semantic content. On the register of the semantic, Hurbinek's speech is 'a nonlanguage that sinks into the abyss of the nonhuman' (ibid.); but, by focusing on the register of the vocalic, Cavarero maintains that the 'act' (ibid.) of Hurbinek's 'sonorous articulations [...] already intones the truth of a voice that is destined to speech and that is thus peremptorily human' (ibid.). Note that Cavarero chooses to highlight Hurbinek's 'sonorous articulations': this is something more than 
mere sonority, mere vocality, presumably distinguished from phone by the modulations and variations around a theme; these variations mark Hurbinek's vocality as articulations and therefore destined for speech (even if not yet speech), which crucially makes them (and by association Hurbinek) 'peremptorily human' (ibid.). 'Rather than being the tragic little exemplar of the nonhuman' Cavarero argues, 'he is the announcement, under infernal conditions, of the quintessence of the human that the voice destines to speech' (ibid.). So not only is the voice destined to speech, it also destines something to speech, this something being the announcement of the quintessence of the human. The voice sets this announcement of the quintessence of the human on its way. It is not the announcement itself, but neither is it 'an inarticulate cry' (ibid. 212):

Rather, his is a voice in which the acoustically perceptible phenomenon of uniqueness, here emphasized by the lack of access to the semantic, modulates itself with experimental variations on a theme; it mimes the musicality of speech, the relational fabric of resonance, the echo that comes from the mouth for the ear of the other (ibid.).

Before Hurbinek's death soon after being found, he '[tasted] the human intonation of speech' (ibid.) which 'tells us that his tragedy is not like that of the "children of the wild" who are raised without human contact' (ibid.); that is, Hurbinek was not an animal.

If for Cavarero what distinguishes the human from the animal is that the voice of the human is 'destined to speech' (ibid. 13), then Hurbinek's case makes this explicit: he was saved precisely because the sonority of his voice expressed modulations and 
variations which demonstrated the destination of his vocalisations to speech, even if this speech was denied to him at his death. Much weight is therefore placed on these modulations and variations - these experimentations on a theme - in that without them Hurbinek would be consigned to Levi's 'drowned' (1998); he would not be 'free' (Levi 1987: 198). It is necessary to pause here and ask a series of related questions. What would Hurbinek's voice be (and consequently what would Hurbinek be) without these variations and modulations which mark his destination to speech? By extension, what work is the variation and modulation doing and what qualifies it for this job? What of the other deportees who bear witness to Hurbinek's articulations? ${ }^{16}$ The concern is that if the prelinguistic voice of the human is only distinguishable from other animals through the voice's 'destination to speech' (Cavarero 2005: 209), then the interruption of this destination renders the one vocalising either infantile or animal. As has been noted, 'infantile' would be the more accurate description (the animal's voice is not destined to speech) except that, in Hurbinek's case, he is already an infant. If, as it has been argued, in the horror of torture there is a separation of phone from logos - a violent splitting of the ambivalence of logos - then following Cavarero voice is also separated to speech, in that speech is voice's essential destination. Torture is an interruption of this essentiality: it works on this essentiality, placing speech an eternal distance away by maintaining the prisoner's singular uniqueness in a state of suspended dissolution. Cavarero ends her account of Hurbinek by noting that ' $[\mathrm{h}] \mathrm{e}$ is the warning - albeit extreme - to every rethinking of ontology that aspires to radically reestablish the bond

\footnotetext{
${ }^{16}$ Cf. Giorgio Agamben's comments on Hurbinek in Remnants of Auschwitz: 'Perhaps every word, every writing, is born [...] as testimony. This is why what is borne witness to cannot already be language and writing. It can only be something to which no one has borne witness' (2002: 38).
} 
between speech and politics' (2005: 212). This is no doubt true, but it is equally true for an ontology which reestablishes the bond between speech and what it is to be human. Cavarero qualifies her account by highlighting that '[t]he voice is invoked here because of its destination to speech, but in such a way that speech is never authorized to erase the reciprocal communication of uniqueness that the voice announces and destines to it' (ibid. 210), but as Cavarero's reading of Hurbinek shows, an interruption of this destination to speech is of central concern.

\section{Voice's 'Destination to Speech'}

This is precisely the same issue one is challenged with in Scarry's account of torture. If one begins by privileging speech as central to the human, as Scarry implicitly does, then one is ineluctably drawn to characterising those whose speech has been radically interrupted as being somehow less than human (whether infantile or animal). Cavarero offers some resources to avoid this conclusion: for Cavarero, voice first communicates not only its essential destination to speech, but uniqueness, a properly human quality:

Every human voice is obviously a sound, an acoustic vibration among others, which is measurable like all other sounds; but it is only as human that the voice comes to be perceived as unique. This means that uniqueness resounds in the human voice; or, in the human voice, uniqueness makes itself sound (ibid. 177).

Focusing on the necessary uniqueness that is expressed through the voice rather than 
the voice's essential destination to speech avoids the essentialisation of speech as the defining characteristic of the human: whether or not Hurbinek's vocalisations reveal their destination to speech (and thus his humanness), his voice is, to begin with and of necessity, expressive of his singular uniqueness which is proper to the human. This would require moving Cavarero's account away from that of Arendt: for both Cavarero and Arendt, the uniqueness of humans and their destination to speech are entwined phenomena and should not be extricated from one another. ${ }^{17}$ Cavarero does not want to do away with speech, but rather wants to insist on the simple fact that speech cannot occur without vocalisation, and that vocalisation communicates uniqueness. Cavarero poses a challenge to any thinking of speech which would refuse this embodied uniqueness in the name of a disembodied realm of metaphysical truths:

By rooting speech immediately in the body, which is the voice's source and chamber of resonance, the vocal first of all situates the act of reciprocal communication over and against a universal conception of language that turns the speakers into fictitious entities (ibid. 206-207).

She goes one:

[...] it is not a matter of overcoming or erasing speech, but rather of keeping the primary sense of speech in proximity to the relational plurality of voices that originate speech, or that materialize it, as it were, by making it sing (ibid. 210).

\footnotetext{
${ }^{17}$ See Arendt's The Human Condition, where Arendt argues 'human plurality is the paradoxical plurality of unique beings [...] Speech and action reveal this unique distinctness' (1998: 176).
} 
But in this process of offering a counter-account of speech, Cavarero not only fuses speech to the uniqueness of voice but also, inevitably, enacts the reverse: voice is concomitantly fused to speech; voice is destined to speech. If it is the case that '[w]hat in speech convokes the relation among speakers is, first of all, the voice' (ibid. 208), then for what reason does uniqueness need to be tied to speech in the form of voice's essential destination? Cavarero argues that 'the voice that sacrifices speech to the subversive effects of an absolute pleasure risks crossing the threshold of the animal realm' (ibid. 209). If one were restricted to a discussion of politics this point would hold some valence, particularly if one is willing to accept that what is proper to politics is speech. And indeed, Cavarero's discussion of the distinction between the animal and the human occurs in a section of For More than One Voice concerned with the politics of logos, articulated via, among others, Arendt. But as can be seen in the example of Hurbinek, Cavarero slips out of this political realm to make speech essential to the communication of human uniqueness via the voice. This seems an unnecessary step if phone already expresses uniqueness, a uniqueness that cannot be stifled by the eradication of semantike.

However, the position that insists on uniqueness being proper to being human as opposed to voice's destination to speech - itself is not immune from challenge: it is necessary to ask after the conditions that make possible the revelation of this uniqueness. If there are such conditions - and surely there must be, since as it has been demonstrated Cavarero seems content to maintain the distinction Aristotle formulates between political animals and mere animals (ibid. 209) - then the assertion of the 
humanity of the body in pain can be undermined by inhibiting the conditions that would allow for the revelation of a person's uniqueness. Put in a different manner, it could be argued that Cavarero's account of vocal uniqueness pays insufficient attention to what Jacques Rancière identifies: that any account of voice and speech is always a partage, a particular partitioning, which first determines which vocalisations count as proper to the human (Rancière 1999). It might be objected that Cavarero is trying to sidestep this debate by emphasising speech's inevitable dependence on the vocalic and the significance not of the content of speech but of the fact that someone is speaking. But this can only take one so far: it is necessary to ask why the vocalisation of an animal does not signify a singular, unique being; and if this question can be asked of the animal it can also be asked of the slave. Cavarero's dependence on an account of human voice's destination to speech now becomes more apparent, even if it does not resolve the tension. What is required is a situation where the asking of the question becomes impossible; a no doubt impossible request for any ontology which can still be described, in one form or another, as committed to a type of humanism. Rather than situating a defense of the human in vocalisation's destination to speech, it would be better to focus on Cavarero's insistence that singular uniqueness is not a uniqueness in general: uniqueness is not proper to Man, or even Woman, but instead proper to men and women (and many others) in their specificity. If this is a non-generalisable uniqueness it is also a uniqueness that can only be articulated in relation to others: uniqueness of necessity only becomes apparent in a plurality of others; one cannot be unique without others to be unique in relation to. The posing of the question 'is this voice the voice of a 
human?' already presumes a generalised, universal conception of the human (as opposed to this or that human) against which the sonorous emission can be measured, and this is precisely what Cavarero is rejecting. The debate is far larger than this article can do justice to, but nonetheless it is important to note that the voice's destination to speech (or lack of it) too easily begs the question of the generalised human in the abstract.

Hurbinek's uniqueness was not effaced because his voice's destination to speech was undermined, just as the uniqueness of the prisoner in the scene of torture that Scarry presents us with is not undermined because the semantike of their logos has been stripped away. Indeed, Scarry's account of torture makes evident something that is not clearly noted in Cavarero's account of horrorism. Throughout Cavarero's examples of horrorism, whether taken from the text Horrorism or retroactively read into the examples of Echo and Hurbinek in For More than One Voice, what is presumed central to horrorism is the 'ontological crime' (2011: 29) of the destruction of singular uniqueness in the helpless. However, Scarry's account of torture offers good reasons to suppose that what is horrifying in horrorism can also be thought of as the opposite of this formulation. That is, not only is killing not proper to horrorism, but further neither is it not simply (or not only) the destruction of singular uniqueness: additionally, it is the placing of this singular uniqueness into a suspended state of dissolution, where the final extinguishing of this singular uniqueness may or may not be threatened, but in either case is always imperilled. On this reading what is especially grotesque in torture is the prolongation of the singularity and uniqueness of the prisoner: the violence of torture is 
premised on the repeated violation of this singular uniqueness which therefore requires a certain sense of 'care' to ensure its sustenance. ${ }^{18}$ Without the prolonged targeting of this singular uniqueness torture would be a generic violence or killing. ${ }^{19}$ This complicates Cavarero's account of the ethical valence of uniqueness and singularity. The violation of the singular uniqueness of the prisoner is not just a particular aim or strategy of torture: this would be a generalised recognition of singular uniqueness (the Human is singular and unique) and thus at best only a partial recognition of singular uniqueness. Rather, the violence of torture precisely depends upon the torturer recognising and exploiting this particular singular uniqueness of this particular person: not a singular uniqueness in general, but revealed in the intimate proximity of the torturer and the tortured. It is this relational intimacy that is exploited in torture, this recognition of a particular singular uniqueness, which in other instances would be a necessary condition for the establishment of reciprocal or nonreciprocal care, while in torture is grotesquely inverted. It is crucial that the torturer maintains, sustains and prolongs the singular uniqueness of the particular person in front of him or her. If in Cavarero's work there is an ethical impetus to understand who someone is rather than what someone is (2000: 50), in the 'idealised' account of torture that Scarry offers us the ethical valence of the 'who' gets inverted: the torturer exploits this 'who' as a means to

\footnotetext{
${ }^{18}$ Cf. Lauren Wilcox' 'Dying Is Not Permitted' in her Bodies of Violence (2015: 49-79).

${ }^{19}$ An important exception to the violence of torture targeting the singular uniqueness of the prisoner are the iconic images of U.S. torture at the Abu Ghraib detention facility. As Cavarero notes, the Abu Ghraib prisoners 'are anonymous bodies, often photographed from behind or with hoods on their heads in order to cancel the singularity of their faces [...] the humiliation consisted of a dehumanization at the hands of the director, who, in the frame of the shots, intentionally covered the facial features of uniqueness and annulled them' (2011: 113). Nonetheless, it would be a mistake to imagine that what is proper to torture is the annulling of uniqueness, even if this was no doubt central to the torture depicted in the images from Abu Ghraib. Torture may resolve itself into an annulling of uniqueness, but first it must recognise and maintain this uniqueness.
} 
the further infliction of suffering. Torture is no doubt an exemplar of what Cavarero means by horrorism, but far from effacing the singular uniqueness of the prisoner the torturer instead offers it a gross reverence.

\section{Romeo's 'Singular Flesh'}

Cavarero's For More than One Voices ends with a discussion of Derrida's reading of Shakespeare's Romeo and Juliet. In this reading Cavarero offers a critique of Derrida, arguing that Derrida overlooks the fact that the 'ontological status' (2005: 235) of Romeo - 'the singularity of the human being loved by Juliet' (ibid.) - is communicated not by his name but rather by his voice. For Cavarero, '[r]ecognizing Romeo's voice, the young girl recognizes the uniqueness of the loved one, separable from the proper name' (ibid.). Cavarero's reading of the scene offers a clear account of her insistence on the voice as an embodied phenomenon expressive of the singular uniqueness of a person, and further that this uniqueness can be accounted for without recourse to the voice's 'destination to speech' (ibid. 210), as it has previously been suggested in this article. What becomes clear in Cavarero's reading is that uniqueness is most apparent when freed from the proper name; that is, when it is communicated through voice, as is the case in Shakespeare's balcony scene where, shrouded in darkness, 'the dialogue unfolds between two people who do not see one another' (ibid. 237). Juliet recognises Romeo's uniqueness by his voice, 'beyond the name itself, beyond speech and even beyond language' (ibid. 238). Romeo's name, although it 'evokes uniqueness' (ibid.), in

fact interrupts who Romeo is by focusing instead on what he is; that is, Romeo is a 
Montague. But as Cavarero notes,

Juliet, as is natural for lovers, does not love what Romeo is but rather who he is. She loves Romeo's uniqueness, and asks him to separate himself from that proper name that, while it announces the uniqueness of the one who bears it, renders the reality of their love improper, in the context of the feud between Montague and Capulet (ibid.).

Romeo's uniqueness is situated in 'the physical, corporeal element of the voice' (ibid.), not his name 'which belongs instead to the verbal register' (ibid.). Crucially for Cavarero, '[t]he name is not flesh; still less is it singular flesh. The voice, however, is' (ibid.). On Cavarero's reading, Juliet wishes to 'separate' (ibid.) Romeo's embodied uniqueness from his disembodied name: 'if the problem is how to separate the embodied uniqueness from the name - from that word, the proper name, that already alludes to the uniqueness - then the voice is what allows for this separation' (ibid. 239). Cavarero's previous coupling of uniqueness to voice's 'destination to speech' (ibid. 209) has been lost here; indeed, it has been actively undermined to the extent that Cavarero is hostile to the name: 'the solution lies', Cavarero suggests, 'in parting from the proper name and in separating it from the embodied uniqueness of the one who bears it. So that this very uniqueness, finally freed from the name Romeo, can take another name' (ibid. 239). Without parting from the proper name one's uniqueness cannot take another name: 'the proper name is nothing but an inessential, and thus modifiable, addition [...] in the voice there resounds a singularity that can leave speech aside [...] The voice is the way in which the exquisitely human uniqueness emits its essence' (ibid. 239-240). Cavarero 
could neither be clearer nor further from an account of uniqueness that situates it in voice's destination to speech.

There is a valorisation of embodied vocality in this account of Cavarero's, precisely to the extent that the embodied voice expresses uniqueness; conversely, it is clear that the proper name should be separated from voice to the extent that the proper name effaces this uniqueness. This theme is present throughout Cavarero's work, explicitly seen in the examples of Echo and Hurbinek whose suffering is tied up in the destruction of their uniqueness, and manifest in the various examples of contemporary violence that Cavarero deploys in Horrorism. To finish, however, it is necessary to return to Scarry's account of torture which complicates this division between, on the one hand, the horrors of the effacing of an embodied uniqueness and, on the other, the human flourishing associated with the sonority of the voice. For if Romeo's uniqueness is to be celebrated as it is expressed in his embodied voice, freed from his disembodied name, then in Scarry's scene of torture we see the reversal of this process. Central to the horrorism of torture is the separation of voice from name. For Scarry, one's use of language and one's sense of 'self and world' (1985: 35) are 'deconstructed' (ibid. 20) in torture, and in contrast the body - the particular, singularly unique body of the one experiencing extreme pain - becomes ever more present. If for Romeo and Juliet the separating of name from voice and body is a condition for the flourishing of their love, in torture the same separation is a condition for a paradigmatic instance of horrorism. If what Juliet loves in Romeo is his 'singular flesh' (Cavarero 2005: 238) expressed first in his voice, in the horror of torture there is the production of 'singular flesh' in the extreme: 
'the body and its pain are overwhelmingly present' (Scarry 1985: 46). Crucially, what changes is not a proper regard for embodied uniqueness in the case of Romeo and Juliet's love and a disregarding of embodied uniqueness in the scene of torture. In torture, as it has already been argued, there is a gross reverence for the singular, embodied uniqueness of the one tortured. Torture imperils this singular, embodied uniqueness - it maintains it in a suspended state of dissolution - but it does so not by disregarding uniqueness but by giving uniqueness its utmost attention. Cavarero is not wrong to recognise the value of uniqueness, its proper expression in the voice, or its indifference to the semantic content of speech. But as Scarry's scene of torture indicates, the horror of horrorism can be aroused not only by the disregarding or annulling of singular uniqueness but also by its grotesque reveration. 


\section{References}

Agamben, Giorgio (2002), Remnants of Auschwitz, New York: Zone Books.

- (2007), Infancy and History, London: Verso.

Améry, Jean (1976), At the Mind's Limits, Bloomington: Indiana University Press.

Arendt, Hannah (1998), The Human Condition, London: University of Chicago Press.

- (2003), 'Total Domination', in The Portable Hannah Arendt, ed. Baehr, Peter, New York: Penguin.

Aristotle (1992), The Politics, London: Penguin.

Avelar, Idelbar (2004), The Letter of Violence, New York: Palgrave Macmillan.

Bourke, Joanna (2011), What it Means to be Human, Berkeley: Counterpoint.

- (2014), The Story of Pain, London: Oxford University Press.

Butler, Judith (2000), Antigone's Claim, Chichester: Columbia University Press.

- (2006), Precarious Life, London: Verso.

Cavarero, Adriana (2000), Tu che mi guardi, tu che mi raccontilRelating Narratives, Oxon: Routledge.

- (2002), Corpo in figure/Stately Bodies, Ann Arbor: The University of Michigan Press.

- (2005), A più voci: Per una filosofia dell'espressione vocale/For More than One Voice, Stanford: Stanford University Press.

- (2011), Orrorismo: Ovvero della violenza sullinerme/Horrorism, Chichester: Columbia University Press. 
- (2015a), 'Narrative Against Destruction', New Literary History, 46:1.

- (2015b), 'Violent Female Bodies: Questioning Thanatopolitics', Graduate Faculty Philosophy Journal, 36:1.

duBois, Page (1991), Torture and Truth, London: Routledge.

Elden, Stuart (2005), 'Reading Logos as Speech: Heidegger, Aristotle and Rhetorical Politics', Philosophy and Rhetoric, 38:4.

Forti: Simona (2015), New Demons, Stanford: Stanford University Press.

Foucault, Michel (1991), Discipline and Punish, London: Penguin.

Levi, Primo (1987), If This is a Man and The Truce, London: Abacus.

- (1998), The Drowned and the Saved, London: Abacus.

Longus (2002), Daphnis and Chloe, Oxford: Oxford University Press.

Pain, Rachel (2015), 'Intimate war', Political Geography, 44.

Panagia, David (2006), The Poetics of Political Thinking, London: Duke University Press.

Rancière, Jacques (1999), Disagreement, London: University of Minnesota Press.

Scarry, Elaine (1985), The Body in Pain, Oxford: Oxford University Press.

Wilcox, Lauren (2015), Bodies of Violence, Oxford: Oxford University Press. 